Randall Peerenboom (ed.), Asian Discourses of Rule of Law, Theories and Implementation of Rule of Law in Twelve Asian Countries, France and the US

London, New York, Routledge Curzon, 2004, 479 p.

Leïla Choukroune

\title{
OpenEdition
}

Journals

Édition électronique

URL : http://journals.openedition.org/chinaperspectives/536

DOI : $10.4000 /$ chinaperspectives.536

ISSN : 1996-4617

Éditeur

Centre d'étude français sur la Chine contemporaine

Édition imprimée

Date de publication : 1 octobre 2005

ISSN : 2070-3449

Référence électronique

Leila Choukroune, «Randall Peerenboom (ed.), Asian Discourses of Rule of Law, Theories and Implementation of Rule of Law in Twelve Asian Countries, France and the US », China Perspectives [En ligne], 61 | september-october 2005, mis en ligne le 18 décembre 2006, consulté le 21 septembre 2020. URL : http://journals.openedition.org/chinaperspectives/536 ; DOI : https://doi.org/10.4000/ chinaperspectives.536

Ce document a été généré automatiquement le 21 septembre 2020.

(c) All rights reserved 


\section{Randall Peerenboom (ed.), Asian Discourses of Rule of Law, Theories and Implementation of Rule of Law in Twelve Asian Countries, France and the US}

London, New York, Routledge Curzon, 2004, 479 p.

Leïla Choukroune

\section{NOTE DE L'ÉDITEUR}

Translated from the French original by Peter Brown

1 This is a work as fascinating as it is ambitious, and whose great quality is its ability to highlight the particular features of the Chinese world through a comparative approach to scholarship. Randall Peerenboom is an expert in, and acknowledged practitioner of, Chinese law, and teaches in the Law Faculty of the University of California. His works have been well known for some time now, although regular readers of China Perspectives may recall that we do not entirely share his analyses concerning the existence of a "thin rule of law" with "Chinese characteristics", conceived as an "alternative version to the Western model of the rule of law"1. In this new work, Randall Peerenboom takes up some elements of these analyses, while enriching them with philosophical and political considerations about "Asian values", or more exactly what he defines as "values in Asia", and what seems to him to correspond to a new, better adapted, formulation, free of polemical dross ${ }^{2}$. Whatever theoretical disagreements one may have, however, the significance of this work very largely transcends them by virtue of the empirical quality of the analyses proposed. 
2 After having confounded a certain number of stereotypes related to the myth of an Asia without law promoted by the tenants of a certain form of orientalism from Max Weber and René David to Ugo Mattei ${ }^{3}$, Randall Peerenboom lays out a set of guidelines that are useful for a general understanding of his project. These concern the reasons for the success or failure of the transfer of law, the relation between the promotion of the rule of law and economic development, the connection between law and politics, and, finally, the influence of globalisation on Asian systems of law which are themselves increasingly internationalised. Avoiding the pitfalls of an over-rigid classification, a sort of grid is nonetheless proposed to the reader in the form of a partial conclusion. Aside from the case of Vietnam that it would be difficult to associate with another normative system, three major divisions appear. These are the competing conceptions of the rule of law in states that are authoritarian, soft-authoritarian or with limited democracy (China, Malaysia, Singapore and Hong Kong); the rule of law, constitutionalism, and transitional justice (Philippines, South Korea, Taiwan, Thailand and Indonesia); mature democracies (Japan, France, USA). While having an overall coherence, this classification does not seem to us convincing as far as China is concerned. The PRC-admittedly less marked ideologically than Vietnam and where the rule of law is increasingly technical-has not entirely broken away from a propaganda discourse or a good many practitioners whose behaviour means that it remains a long way from the normative and institutional systems of Hong Kong or Singapore.

3 No fewer than twelve Asian legal systems are very carefully scrutinised in this work by acknowledged experts, who often have a broad experience as practitioners behind them. It is also worth noting that these studies are supplemented by an analysis of the evolution of the rule of law in the United States and France. Although no doubt less original, this serves as a very handy reference tool, which is how it is conceived. It would be futile to attempt to account in a few lines for the range of research offered here without doing a disservice to its quality. Let us simply state that the brilliant chapters devoted to Vietnam by John Gillespie, and to India by Upendra Baxi, appear to us as enlightening for an understanding of the development of Chinese law today as Sean Cooney's observations on Taiwan, or those on Hong Kong by Albert H.Y. Chen and Anne S.Y. Cheung, or by Li-Ann Thio's on Singapore.

Overall, this is a particularly well documented work, which at the same time makes use of a very rich and readily accessible critical apparatus. It thus rises to the challenge of the empiricism it posits as a postulate. One may, however, regret the absence of certain states like Cambodia-about which much could have been written-or, in a different vein, Burma and North Korea, although the lack of transparency of these systems would no doubt have encumbered even more the empirical analysis which underpins the work.

5 If we were to single out just one contribution that Asian Discourses of Rule of Law offers scholars of the chinese world, it would be the healthy and helpful putting in perspective of a regime which, despite being complex and with its own peculiarities, is far from unique, not only by virtue of the multiple normative borrowings granted, but also due to its increasing involvement in globalisation. By seeing how the transformations in Chinese law and society are integrated into a vaster set of mutations -and vice-versa-the reader learns to cast a measured, critical gaze over normative integration, whether it be upward or downward, resulting from imposed transfers or hybridisations, tending either towards unification or harmonisation, and having an 
influence or not on the political regime. Everything happens, therefore, as if, to borrow a concept dear to Mireille Delmas-Marty, we were witnessing a normative integration "with a variable geography and geometry"4. Of course, such integration would still have to work towards respect for an "ordered pluralism" at whose core formal provision would need to be made for the protection and guarantee of political, economic, social and cultural rights of citizens.

6 As rich as this work is, it constitutes but the foundation stone of a large edifice whose construction has been planned over several years, in order to help provide a better understanding of the legal systems in Asia and their relations to economic development, democracy, the protection of human rights and the geopolitical stability of the region and the world 5 . Imbued with this ambition, the writers-who are obviously not put off by subjects fraught with difficulty-have prepared a second volume devoted to the conception and implementation of human rights in Asia. While warmly recommending this first collection of texts, we look forward therefore with great interest to the publication of Human Rights in Asia, Values, and Legal Systems, with Comparisons to France and the United States ${ }^{6}$.

\section{NOTES}

1. See Randall Peerenboom, China's Long March toward Rule of Law, Cambridge University Press, 2002, 673 p. Whereas a "thick theory" or "substantive theory" of the rule of law would incorporate elements of political morality like the forms of government, the economic models or the various conceptions of human rights, a "thin theory" would put forward formal or instrumentalist aspects of the rule of law that would rest on a system of laws that are "general, published, prospective, clear, coherent, applicable, stable and implemented". See our review in China Perspectives, No. 47, May-June 2003, pp. 74-76.

2. Randall Peerenboom has long worked on the theme of Asian values, see for example "Beyond Universalism and Relativism : The Evolving Debates about Values in Asia", Indiana International and Comparative Law Review, 2003, pp. 1-85.

3. Thus for Max Weber, there "did not exist in China a judicial corps, because there did not exist any lawyers in the Western sense. And these did not exist because the patrimonialism of the Chinese charity state, with only a weak authority, was not based on any formal development of secular law". Cf. Max Weber, Confucianisme et Taoïsme, Paris, Gallimard, 2000, p. 215.

4. See Mireille Delmas-Marty (ed.), Critique de l'intégration normative, (A Critique of Normative Integration) Paris, PUF, 2004.

5. See p. XVI.

6. Edited by Randall Peerenboom, to be published by Routledge Curzon in January 2006. 